Vol. XIX No. 2

\title{
Summer Observations of Birds In Northern Saskatchewan, 1960
}

by George W. Scotter, Canadian Wildlife Service, Edmonton

The writer and L. E. Erickson were engaged in a study for the Clanadian Wildilife Service of the effects of fire on the winiter range of barren-ground caribou (Rangifer arcticus arcticus) in extreme north-central Saskratchewan from late May unitil September 15 of 1960. Since little is known of bird distribution in the northern portion of Saskatchewan, field notes were made on the birds encountered.

The study area was located in the Black Lake region, from $59^{\circ} \mathrm{N}$. latitude to the Saskatchewan-Northwest Territories boundary and from $104^{\circ}$ $\mathrm{W}$. to $106^{\circ} \mathrm{W}$. longitude. The localities in which observations were made are shown on the accompanying map.

On the basis of topography, geology, and vegetation, two major habi- tat divisions can be recognized. North of a line extending from the Fond du Lac River to east of Black Lake the region is covered with forests of black spruce (Picea mariana), except for fire-disturbed areas which support white birch (Betula papyrifera). jack pine (Pinus banksiana) predominates in the region south of this line. Rowe's (1959) description of the forest regions of Canada placed the jack pine forest in the Athabascia Southern Section, and the northern forest in the Northwest Transition. Plants within these areas have been reported by Scotter (1961).

The geology of the area was outlined by Furnival (1941a and 1941b). The northern section is characterized by Precambrian rocks which are considerably folded and faulted. Elon-

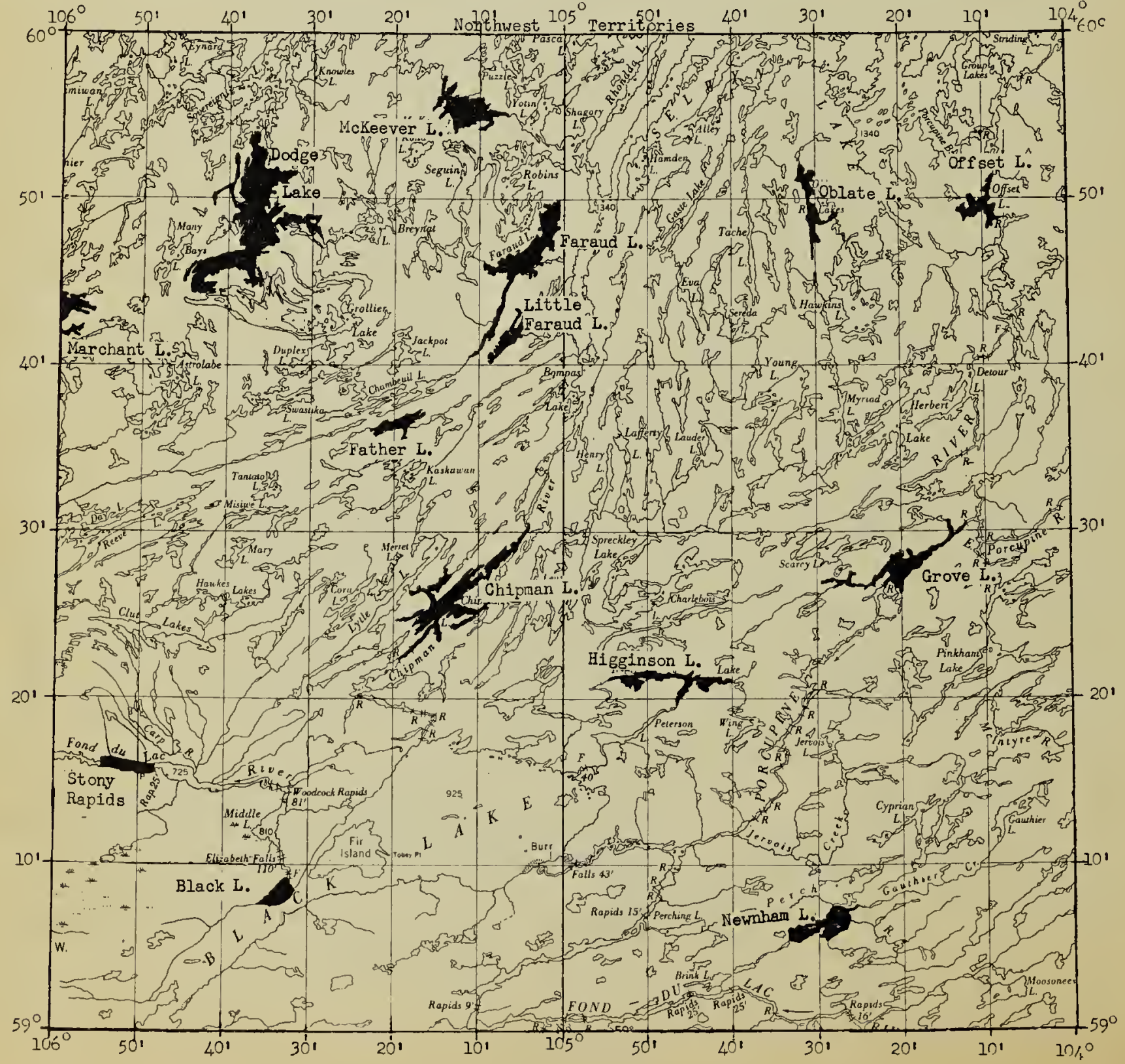


gated lakes and steep hills dominate the topography, while the southern section is flat-lying Athabasca series sandstone of a later Precambrian age.

The region is generally considered to be within the Hudsonian life zone. Dice (1943) included the region in the Hudsonian biotic province.

No previous observations of birds in this region of northern Saskatchewan are known to the writer. Unpublished records for the area west of this region include work by Francis Harper in 1914 and 1920, T. I. Shortt in 1945, and R. W. Nero in 1960 . Preble (1908), based largely on notes received from $R$. MacFarlane, made occasional mention of bind distributions in northern Saskatchewan.

Since other duties precluded observations during certain periods, the annotated list of species which follows is not a complete list of the birds in the region. No search for nests was made, but several were found during the course of other field work and furnish some informaition on breeding ranges. The annoitated list of observations is arranged in accordance with the A.O.U. Check-list (1957). The dates and places of the observations along with notes of interest are included. Relative abundance is signified by the terms "common," "fairly common," "scarce," "rare." All doubtful identifications were omitted from the list.

\section{ANNOTATED LIST OF SPECIES}

Common Loon Gavia immer.Common. Grove L. June 21; Offset L. June 29; Oblate L. July 2; McKeever L. July 8; Faraud L. July 14; Sitony Rapids July 28; Marchant L. July 31; Dodge L. August 7; Flather L. August 9; Newnham L. August 17; Chipman L. August 30.

On July 2 on an island in Oblaite Lake we found a nesit with two eggs, the site consisting of nothing more than a slight depression in the soil. The nest was surrounded by a thick scrub cover on three sides and open to water on the fourth. As the nest was approached the bird slid into the water and began an interesting performance. By beating its wings vigorously, the loon reared high into the air until only the tail and feet re-



Common Loon nest on an island in Oblate Lake, July 2, 1960.

mained submerged. Beating of the wings, accompanied by several sharp calls, caused no small amount of commotion. These anitics were repelated three or four times before the bird disappeared. Several hours later the nest was still unoccupied.

Canada Goose Branta canadensis.Scarce. Higginson L. June 8; Grove L. June 18; Offset L. June 25. Eleven geese were abserved on Grove Lake. The birds appeared to be nonbreeders and were likely sub-adults of the past year's hatch. Carex (Carex deflexa), bluejoint (Calamagrostis canadensis) and woodland horsetail (Equisetum sylvaticum) on a recently burnt area were used as food by these birds. Two goslings were observed at Offiset Lake on June 25.

Mallard Anas platyrhynchos. Fairly common. Higginson L. June 10; Grove L. June 21; Offset L. June 25; Newnham L. August 17. A brood of ducklings was present on a small pond adjacent to Grove Lake on June 21. Labrador tea (Ledum groenlandicum) sheltered a nest lined with dry grass and sedge containing 8 eggs, on an island in Offset Lake, observed June 25.

Pintail Anas acuta.-Scarce. Higginson L. June 11.

Green-winged Teal Anas carolinensis.-Scarce. Higginson L. June 11. Three birds were observed in a shel- 
tered marshy bay on the south side of the lake.

Lesser Scaup Aythya affinis.Scarce. Higginson L. June 11.

Common Goldeneye Bucephala clangula.-Scarce. Higginson L. June 11.

Bufflehead Bucephala albeola.Scarce. Higginson L. June 11.

Surf Scoter Melanitta perspicillata. -Scarce. Higginson L. June 11; Faraud L. July 15; Newnham L. August 17.

Common Merganser Mergus merganser.-Flairly common. Higginson L. June 10; Grove L. June 25; Offset L. June 27; Oblaite L. July 2; McKeever L. July 8; Father L. August 9; Newnham L. August 17.

Goshawk Accipiter gentilis. Scarce. Stony Rapids September 10.

Red-tailed Hawk Buteo jamaicensis -Scarce. Oblate L. Juily 6; Faraud L. July 16; Newnham L. August 20.

Bald Eagle Haliaeetus leucocephalus.-Fairly common. Black L. June 5; Higginson L. June 8; Grove L. June 17; Oblate L. July 2; McKeever L. July 8; Newnham L. August 17.

A nesting site at Grove Lake was situated in the tallest jack pine tree within a quarter mile of the lake, and was occupied by two eaglets. Both parenits were active in the care of the eaglets, but they offered no threats when the young were photographed at close range. Remains of nonthern pike (Esox lucius) were abundant in and around the nest and it appeared that this fish constituted a large portion of the eagles' diet. The presence of northern pike may also suggest that the eagles were catching this fish, which prefers shallow water, rather than picking up dead fish around the lake shore as generally reported. Lake trout (Salvelinus namaycush) which were numerous in the lake, prefer deeper water and likely were more difficult for the eagles to capture. If fish were picked up from the lake shore an almosit equal abundance would be expected.
Osprey Pandion haliaetus.-Scarce. Sitony Rapids July 28. This bird was observed flying along the Fond du Lac River.

Pigeon Hawk Falco columbarius.Scarce. Offset L. June 29; Dodge L. August 7; Newnham L. August 25.

Sparrow Hawk Falco sparverius.Scarce. Black L. June 5; Higginson L. June 8; Stony Rapids July 20.

Spruce Grouse Canachites canadensis.-Common. Higginson L. June 14; Grove L. June 21; Offset L. June 27 and June 30 ; Oblate L. July 2; McKeever L. July 8; Faraud L. July 14; Stony Rapids July 20; Marchant L. August 2; Dodge L. Augusit 7; Father L. August 13; Newnhaim L. August .17; Chipman L. August 30.

On June 30 a nest with only 5 eggs (10-12 is a more common number) was found in a muskeg. A brood of about seven were seen (July 2) in a mature black spruce forest ait Oblate Lake. Spruce Gmouse were the most common bird of the region and mature black spruce forests were their favored habitat. Black flies and lichens appeared to be part of their summer diet.

Sharp-tailed Grouse Pediocetes phasianellus.-Rare. Marchant L. July 31. This observation was made in a recent burn approximately 32 miles northwest of Stony Rapids and appears to extend the known range of this bird in Saskatchewan.

Spotted Sandpiper Actitis macularia.-Scarce. Higginson L. June 14; Grove L. June 25; Stony Rapids July 20; Dodge L. August 7; Father L. Augusit 9; Newnham L. Augusit 17.

Solitary Sandpiper Tringa solitaria. -Scarce. Faraud L. July 14.

Lesser Yellowlegs Totanus flavipes. -Scarce. Higginson L. June 11; Offseit L. June 30 .

Bonaparte's Gull Larus philadelphia.-Common. Grove L. June 25; Offset L. June 27; Oblaite L. July 2 and July 4; McKeever L. July 8 (nest with three eggs); Farud L. July 15; Stony Rapids July 20; Marchant L. July 31; Dodge L. August 7; Newnham L. August 17; Chipman L. August 30 . Three young gulls were observed, July 4, on Oblate Lake, and 


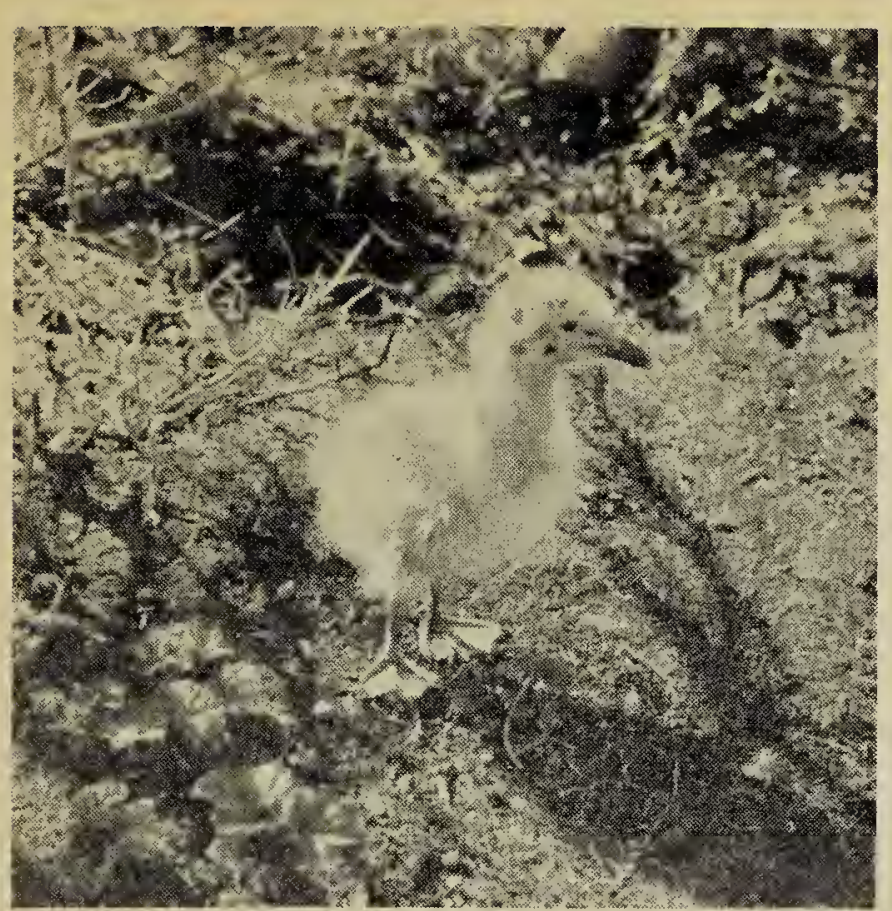

One of three young Bonaparte's Gulls found at Oblate Lake, July 4, 1960.

one was later photographed. The adult birds made vociferous threats and dived at us while the young were on the water, but threaits were discontinued when the young reached a small island.

Common Tern Sterna hirundoFairly common, Grove L. June 18 and June 21; Oblate L. July 2; McKeever L. July 8; Faraud L. July 15; Stony Rapids July 20; Marchant L. July 31; Dodge L. August 7. Five nests, with 3 eggs in each, were located July 8, on an island scarcely more than 20 feeit long and 12 feet wide. The nests were fully exposed and consisted of nothing more than dry plant stalks in a shallow depression.

Common Nighthawk Chordeiles minor-Fairly common, Higginson L. June 11; Grove L. June 18; Stony Rapids July 20; Marchant L. July 31; Dodge L. August 7; Newnham L. August 17.

\section{Belted Kingfisher Megaceryle} alcyon-Scarce, Grove L. June 25.

Yellow-shafted Flicker Colaptes auratus-Fairly common, Black L. June 3; Higginson L. June 8; Grove L. June 18; McKeever L. July 8; Faraud L. July 14; Newnham L. August 17.

Black-backed Three-toed Woodpecker Picoides arctictus - Scarce, Oblaite L. July 4.
Barn Swallow Hirundo rusticaRare, Stony Rapids July 20. Barm swallows were nesting above the door of the storage shed owned by the Department of Natural Resources. Only one pair of birds was observed in this region.

Gray Jay Perisoreus canadensis.Common, Higginson L. June 8; Grove L. June 18; Offset L. June 30; Oblate L. July 2; McKeever L. July 8; Faraud L. July 16; Marchant L. August 2; Dodge L. Augusit 7; Father L. August 9; Newnham L. August 17. The Gray Jay was a common visitor at our campsites.

Common Raven Corvus corax.Fairly common. Stony Rapids June 2; Higginson L. June 8; Grove L. June 18; Offiset L. June 25; Oblate L. July 2; McKeever L. July 8; Marchant L. Auguist 2; Dodge L. August 7; Father L. August 9; Newnham L. August 17; Chipman L. August 30. Old nesting sites were common on rocky ledges at McKeever Lake.

Black-capped Chickadee Parus atricapillus.-Scarce, Flanaud L. July 14; Sitony Rapidis July 20.

Boreal Chickadee Parus hudsonicus -Fairly common, Marchanit L. August 2; Newnham L. August 17; Chipman L. August 30.

Robin Turdus migratorius.-Fairly common, Stony Rapids June 2; Higginson L. June 8; Grove L. June 18; Offseit L. June 25; Oblate L. July 2; McKeever L. July 8; Faraud L. July 16; Marchant L. August 2; Dodge L. August 7.

Hermit Thrush Hylocichla guttata. -Fairly common, Higginson L. June 8; Grove L. June 17; Offset L. June 25; Oblate L. July 4; Faraud L. July 14; Marchant L. August 2.

Ruby-crowned Kinglet Regulus calendula.-Rare, Stony Rapids July 20.

Yellow Warbler Dendroica petechia - Scarce, Stony Rapids June 2; Newnham L. August 25.

Myrtle Warbler Dendroica coronata. Common, Black L. June 3, nest with three eggs; Higgins L. June 8; Grove L. June 20; McKeever L. July 8; Stony Rapids July 20; Marchant L. August 
2; Father L. August 9; Newnham L. August 17; Chipman L. Augusit 30.

Northern Waterthrush Seiurus barocensis.-Scarce, Father L. August 14; Newnham L. August 17.

Rusty Blackbird Euphagus carolinus.-Scarce, Newnham L. August 25.

White-winged Crossbill Loxia leucoptera.-Scarce, Oblate L. July 5; Faraud L. July 14.

Slate-colored Junco Junco hyemalis -Common, Black L. June 3; Higginson L. June 8; Grove L. June 22; Offset L. June 30; Oblate L. July 4; McKeever L. July 8; Faraud L. July 14; Stony Rapids July 20; Dodge L. August 7; Newnham L. August 17; Chipman L. August 30. The nest found June 3 at Black Lake rested on the ground in the shelter of Labrador tea and contained 3 eggs, while the nest at Oblate Lake, July 4, inside a muskeg hummock, contained 5 eggs.

Chipping Sparrow Spizella passerina.-Scarce, Stony Rapids June 1.

White-crowned Sparrow Zonotrichia leucophrys.-Scarce, Stony Rapids June 2; Higginson L. June 11; Grove L. June 18; Offset L. June 25; Oblate L. July 2; McKeever L. July 8; Faraud L. July 15; Marchant L. July 31; Dodge L. August 7.

Song Sparrow Melospiza melodia.Scarce, Stony Rapids June 1; Grove L. June 25.

\section{LITERATURE CITED}

American Ornithologists' Union 1957. Checklist of North American birds. 691 pp.

Dice, L. R. 1943. The biotic provinces of North America. Ann Arbor, University of Michigan Press. 78 pp.

Furnival, G. M. 1941a. Porcupine River, Northern Saskatchewan, Geol. Surv. Canada Map 658A.

Furnival, G. M. 1941b. Sitony Rapids, Northern Saskatchewan, Geol. Surv. Canada. Map 659A.

Preble, E. A. A biological investigation of the Athabasca-Mackenzie region. U.S. Dept. of Agriculture, Bur. Biol. Surv. N. Amer. Fauna No. 27. 574 pp.

Rowe, J. S. 1959. Forest regions of Canada. Dept. of Northern Affairs and National Resources, Forestry Branch Bull. 123. 71 pp.

Scotter, G. W. 1961. Botanical collections in the Black Lake region of Northern Saskatchewan (1960). Blue Jay, 19:28-33.

\section{BALD EAGLE CENSUS}

Alarmed by persisitent reports of a downward trend in the population of the Bald Eagle the National and Canadian Audubon Societies have anncunced a continental study aimed at determining the sitatus of the species. The project will cover at least five years.

The first step will be an inventory. Once numbers have been estimated and reproductive success measured future checks will disclose population trends. The eagle program is under the direction of Alexander Sprunt IV.

Your assistance is earnesitly solicited. If you have any information please write: Canadian Audubon Society, 423 Sherbourne Street, Toronto 5 .

\section{COLOURED SNOWY OWLS}

A number of Snowy Owls were marked this spring in Wisconsin by spray painting or dyeing a portion of the plumage with a variety of colours. Anyone who sighted one of these owls moving north is asked to report date, location, and colour marking (note the colour and the part of the body coloured, e.g. right or left wing, preferably sketching the bird), to "Operation Snowy Owl", Plainfield, Wisconsin.

\section{THE BLUE JAY B.OOK SHOP OFFERS}

Prairie Wildflowers,

L. T. Carmichael.

Field Guide to the Western Birds (rev. ed.) R. T. Peterson $\$ 5.95$

Birds of the Saskatchewan River, Houston and Street $\$ 1.50$

Guide to Sask. Mammals, H. Beck .50

Pocket Guide to Birds

Allan Cruickshank

Sask. emblem hasti-notes (lily, sharp-tail)

Slides of museum habitat cases, each $\$ 1.00$

Coloured cards of habitat cases, set of seven

\$1.25 and $\$ 1.35$ 